\title{
MIGUEL LEÓN-PORTILLA AND ARCHAEOLOGY
}

\author{
Leonardo López Luján \\ Museo del Templo Mayor, Guatemala 60, Colonia Centro, 06060 Ciudad de México, Mexico
}

\begin{abstract}
After a long hospital stay, Mexican historian and philosopher Miguel León-Portilla passed away on October 1, 2019, at the age of 93. His prodigious work is known throughout the world because classics such as La filosofía náhuatl (León-Portilla 1956), Visión de los vencidos (León-Portilla 1959), Los antiguos mexicanos a través de sus crónicas y cantares (León-Portilla 1961), Las literaturas precolombinas de México (León-Portilla 1964), Trece poetas del mundo azteca (León-Portilla 1967), and Teatro náhuatl (León-Portilla 1974a), among others, have been published and republished dozens of times in a multitude of languages. Professor William R. Fowler kindly asked me to write an obituary for Ancient Mesoamerica and suggested that I focus my text on the contributions that Dr. León-Portilla made in my field, that is, archaeology. To this end I have decided to offer the readers of this journal an English translation of a brief discourse I presented on February 22, 2016 (Figure 1), in the context of a tribute paid to "Don Miguel" on the occasion of his ninetieth birthday, which was organized by the Universidad Nacional Autónoma de México.
\end{abstract}

Exactly nine decades after his birth and close to completing his seventh tlalpilli or 13-year cycle, Miguel León-Portilla exemplifies for all of us what is known in the Nahuatl language as an omacic oquichtli, that is to say, a "mature man" (Sahagún 1961:12; León-Portilla 2004a, 2011). Let me clarify, however, that for ancient Mexicans such a condition was not achieved by simply tallying the days, weeks, 20-day months, or years of one's life, but by gradually acquiring a resolute and vigorous character that was also prudent, insightful, and discrete. The omacic oquichtli was considered to be a seasoned and consummate individual, in short, someone replete with life experiences in whom nothing-absolutely nothing - was lacking. In metaphoric terms, it was said that he was the "master of a face" and also the "master of a heart"; but not just any face, rather the face of a sage, and not just any heart, but one that is rock solid and as resistant as the trunk of a tree.

To Ana Carolina Ibarra and Eduardo Matos Moctezuma: I owe the privilege of being with you today on this splendid stage [in the Juan Ruiz de Alarcón Theater on the campus of the Universidad Nacional Autónoma de México [UNAM], in Mexico City], as well as the opportunity to talk about the "mature man" to whom this February 22 we pay homage for his 90 years spent here on tlalticpac, the face of the earth (Figure 2). I have been tasked with speaking to you about the profound imprint that Miguel León-Portilla has left on the field of archaeology, that "discipline of ancient things," which is my life's desire and passion. A persistent clock will not let me do justice to an entire legacy, but it should at least allow me to offer a few snapshots from the past of an individual and his circumstances, which continue to have repercussions in our present.

First, I would like to go back to the distant year of 1963, when an impetuous Miguel was chosen to direct the former Instituto de Historia [now Instituto de Investigaciones Históricas] of the UNAM (León-Portilla 1993). After receiving the baton from a prestigious archaeologist, Pablo Martínez del Río, the new director found himself heading a research center urgently in need of reorganization. Without hesitation, he took decisive measures, one of which we now recognize as visionary: creating the institute's Anthropology Section, putting the tireless Juan Comas Camps in charge, and thus bringing together the impetus of several veritable giants in this area of knowledge including Paul Kirchhoff, Pere Bosch Gimpera, Morris Swadesh, Fernando Horcasitas, Santiago Genovés, and Yolanda Lastra. Additionally, in order to strengthen archaeological studies, he enlisted a pair of young specialists-Jaime Litvak and Carlos Navarrete-who were beginning to shine. As one might expect with such a distinguished group, the Anthropology Section quickly blossomed to the point of soon having to move from the seventh to the first floor of the Tower of Humanities. In fact, the success of this melting pot of exceptional minds led León-Portilla, with the support of the president of the university, Guillermo Soberón, to establish the Instituto de Investigaciones Antropológicas in 1973, which currently houses a team of about 50 specialists, many of them devoted body and soul to archaeology.

Another key moment in the history of my discipline dates from the period between 1987 and 1992 when Miguel León-Portilla was our brilliant ambassador to UNESCO (León-Portilla 1993). During those challenging years in Paris, he not only successfully navigated the turbulence of an institution that was in full political and economic crisis, but also spearheaded a process that altered the course of some of the most important archaeological sites in Mexico. I am specifically referring to the five candidates that León-Portilla put before the plenary of that organization of the United Nations to be added to the roster of World Heritage Sites. Thanks to compelling applications and skillful diplomacy, Teotihuacan, Monte Albán, Palenque, Chichen Itza, and the Templo Mayor of Tenochtitlan-the latter including a large part of the historic center of Mexico City-came to join that exclusive list. As Miguel has repeatedly pointed out, this designation not only represents an enormous privilege, but also a major responsibility for those of us in charge of safeguarding these sites.

A third snapshot, corresponding to the year 1959, brings us to the beginning of Estudios de Cultura Náhuatl, the internationally renowned journal founded by the eminent Ángel María Garibay K. and continued with erudition and fortitude by Miguel León-Portilla (Garibay K. 1959). From the very first volume, archaeology has 


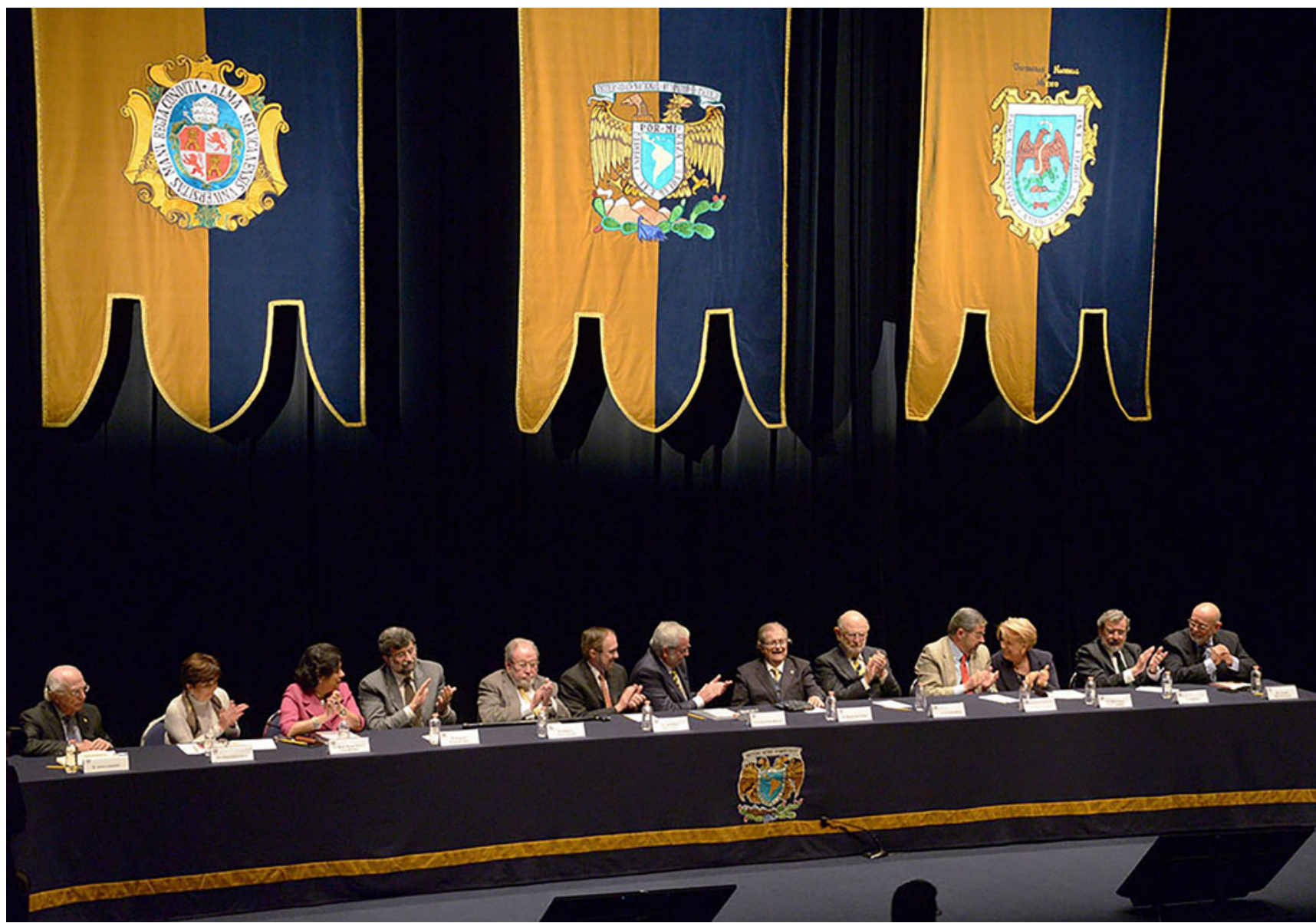

Figure 1. The tribute paid to Dr. Miguel León-Portilla on his ninetieth birthday. Photograph courtesy of the Proyecto Templo Mayor.

been present in this serial publication (López Luján 2015b), even though its essential vocation is the study of "all kind[s] of documentary sources, indigenous codices, and texts of historical, ethnographic, linguistic, or cultural importance in relation to the various Nahua peoples, [of] the pre-Columbian, colonial, and independent Mexico periods" (http://www.historicas.unam.mx/publicaciones/ revistas/nahuatl/nahuatl.html). Such a presence, for those who like statistics, is easily corroborated by perusing the tables of contents of the 49 volumes that have been published to date. Among the 996 contributions listed, 100 of them are wholly or partly dedicated to archaeology, which together represent no fewer than 1,783 pages. These tables of contents also reveal the richness and diversity of this "archaeological corpus," in addition to a clear predilection for certain theoretical positions, methodologies, and topics. For example, immediately apparent is a preference for iconographic analyses of isolated sculptural monuments or groups, in order to reveal their historical and symbolic content as well as their aesthetic value. Equally recurrent are articles on urban centers, especially their ceremonial precincts, where the finest temple-pyramids, plazas, shrines, and tombs are usually concentrated. Something similar can be said of the most sophisticated intellectual expressions of the pre-Hispanic world such as writing, mathematics, the calendar, and astronomy, which are often examined in the pages of Estudios de Cultura Náhuatl. To all of this I must add the reviews and obituaries Miguel wrote concerning the protagonists of Mexican archaeology and anthropology (León-Portilla 1974c, 1980, 1989, 2002).
Obviously, the role of our honoree in the field of archaeology is not limited to his highly successful initiatives in the realms of university administration and politics, cultural diplomacy, or journal publication. Rather, the field of ideas is where we will find his greatest achievements. Let me say at the outset that Miguel León-Portilla, with an acute sense and clear vision, has explored practically every corner of the ancient world, and is often at the forefront in uncharted areas.

A prime example of this is his historiographical research on what he himself has called "protoarchaeologists," undoubtedly beginning with those Mexica and Tlaxcaltecans of the fifteenth and sixteenth centuries who used to explore with fascination the desolate ruins of Teotihuacan and Tula-Xicocotitlan with the express purpose of exhuming all sorts of relics from their depths (León-Portilla 2008). In this same area we may include León-Portilla's biographical studies of the dragoon captain from Luxembourg, Guillermo Dupaix, and the naturalized French artist, Jean-Frédéric Waldeck. Dupaix, as is well known, headed the Royal Antiquarian Expedition in New Spain, an ambitious and ill-fated endeavor that was able to complete only three outings between 1805 and 1809 (León-Portilla 1971, 1978c), while Waldeck scrutinized the ancient buildings of Palenque and Uxmal in the 1830s vainly searching for evidence of contacts with Egypt, Carthage, Niniveh, and India (León-Portilla 1997). In an analogous manner, Miguel has documented the successive passage of "proto-" and professional archaeologists through the same site-as occurred in the paradigmatic case of Xochicalco (León-Portilla 1995b) —and, conversely, 


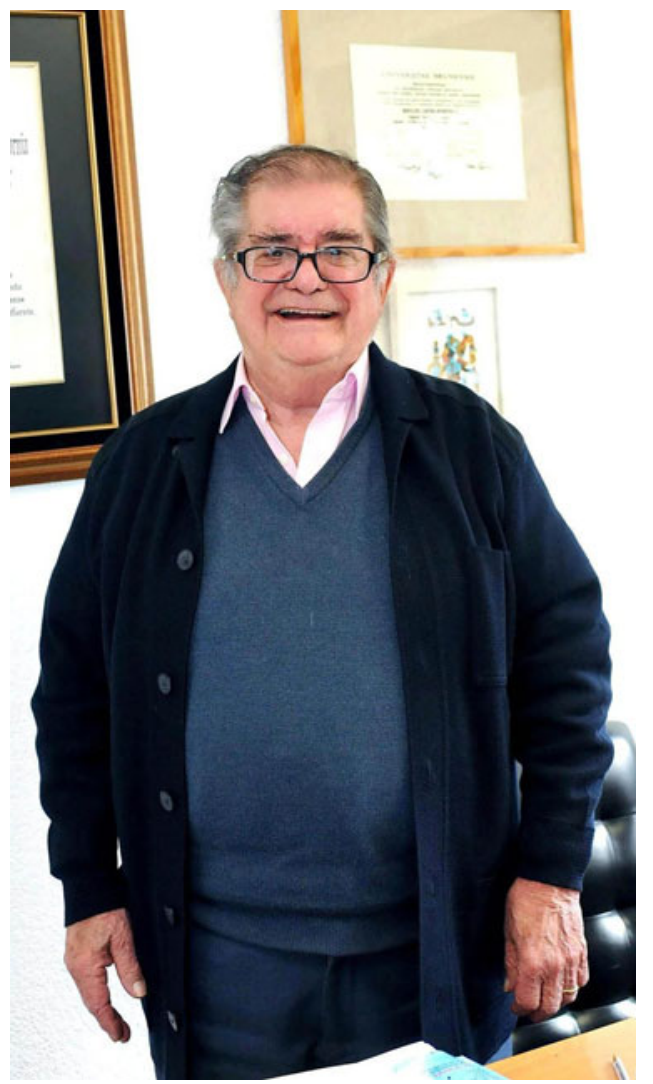

Figure 2. An always smiling Miguel in his office at Universidad Nacional Autónoma de México, February 2016. Photograph courtesy of the Proyecto Templo Mayor.

has traced the explorations of one man of science in a multitude of sites, illustratively following his dear uncle, Manuel Gamio (Figure 3), through Chalchihuites, Azcapotzalco, Tenochtitlan, Teotihuacan, and Kaminaljuyu (León-Portilla 1960, 2009).

León-Portilla also has successfully ventured into Mexico's ever uncertain remote past. And, when his research requires him to go back centuries or even millennia, he has been accompanied by exceptional guides, nourished by the works of the most renowned archaeologists of his time, including Jorge Acosta, Ignacio Bernal, Alfonso Caso, Richard MacNeish, Ignacio Marquina, René Millon, Eduardo Matos Moctezuma, Eduardo Noguera, Román Piña Chan, César Sáenz, and Laurette Séjourné, to name only a few (León-Portilla 1974b). This is how Miguel has managed to heed rigorously the call of his wide range of interests concerning our ancestors.

In this respect, the topic of technology recurs in his publications. For instance, let me say that he has written many pages on mining and metallurgy, from mineral exploitation using wells, tunnels, and shafts to the production of ornaments and implements out of gold, silver, copper, tin, and lead (León-Portilla 1978b, 1984). And something similar can be said about his curiosity for hydraulics, from the Olmec cisterns and channels of San Lorenzo, to the chinampas and drainage systems of Teotihuacan, to the dams and aqueducts that scored Lake Tetzcoco during the Postclassic (León-Portilla 1992a). All of this has led Miguel León-Portilla to ponder how, in spite of multiple technical limitations and an absence of draft animals, Mesoamericans independently achieved a level of civilization equal to the societies of the Tigris and Euphrates, Nile, Indus, and Huang Ho river valleys. His solution to such an elusive question is that here they followed evolutionary paths that differed from those in the Old World, but that all of them, in the end, converged in the establishment of urban life, the production of fine art, and the creation of writing systems (León-Portilla 1974d, 2004b).

The heights of León-Portilla's insights are also discernable in his taste for general historical overviews of entire areas such as Mesoamerica and the Andes (León-Portilla 1974b, 1974d, 1979, $2004 \mathrm{c}$ ), or regions rarely considered in the social sciences such as the peninsula of Baja California (León-Portilla 1983, 1995a; León-Portilla and Piñera Ramírez 2011). In that geographic and cultural blind alley he has reconstructed 12 millennia of tradition with brief but masterly treatments based on data pieced together from the excavation of shell works, rock shelters, and open-air camps and compared with the accounts of sailors, pearl fishermen, and missionaries.

As a lover of the exegesis of the spoken and written word, León-Portilla has paid particular attention to the material recording of knowledge (León-Portilla 1989, 1992b, 1996, 2002). Thus he has examined ceramics, murals, and stone monuments for their systems of images and glyphic notations that made possible the preservation and transmission of ideas. And, conversely, his careful study of the spoken and written word, in Nahuatl as well as Castilian and Latin, has helped him unravel the meaning of enigmatic sculptures and paintings, no matter if they take the form of feathered serpents, decapitated deities, or majestic sovereigns (León-Portilla 1974b, 2004a, 2007). This is how he manages to breathe life into inert material remains with no apparent reason, which proliferate in our museums and archaeological sites.

As you may have guessed, among the contributions that I personally value most are the ones that León-Portilla has made concerning the Templo Mayor in collaboration with my mentor Eduardo Matos Moctezuma (Alcina Franch et al. 1992; LeónPortilla 1978a, 1982, 1987; León-Portilla et al. 1981). In the 1970 s and 1980s, they joined forces to show how the archaeological and historical data complement and corroborate each other. Combining the methods of their respective disciplines they came to understand the transformative construction phases of this pyramid over the course of two hundred years, and, even more important, the political and religious context that led to each change.

In closing, I would like to say that just a couple months ago I invoked León-Portilla's teachings before a group of young archaeologists, while excavating at the foot of the Templo Mayor (López Luján 2015a; Pedraza Rubio et al. 2017). I explained to them how, based on pictographs and chronicles, Miguel and Eduardo had recognized in the building's physiognomy the material representation of the archetypal Coatepec (Serpent Mountain), an evocation of the myth of the birth of the sun, Huitzilopochtli, and a theater for reenacting the defeat of the moon, Coyolxauhqui (León-Portilla 1978a:45-46).

In the middle of the talk, we were struggling to free from the mortar an offering that a Mexica priest had devotedly deposited five hundred years earlier (Figure 4). All of a sudden, a ray of sunlight revealed the presence of several gold ornaments belonging to the lunar goddess: they were the luminous earpieces of Coyolxauhqui, accompanied by the bells worn on her cheeks, which divulged her identity (Figure 5). The priest had surrounded these insignias with obsidian points and flint knives, perhaps to denote the setting of the moon at the base of the mountain. The next day, four beautiful representations of hearts, also made of gold, appeared below the assemblage (Figure 6). There is no 


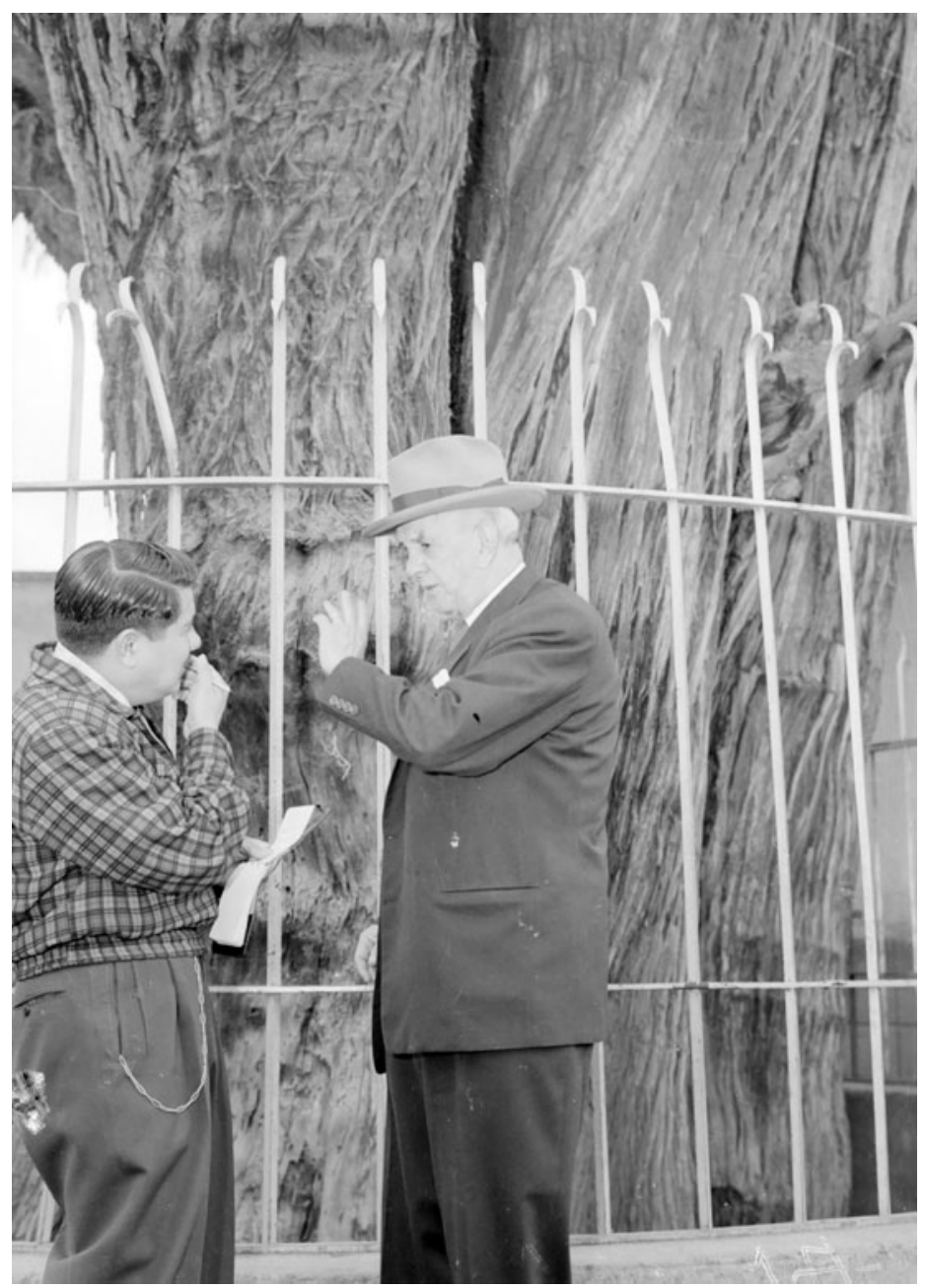

Figure 3. A young Miguel with his uncle Manuel Gamio evoking the "Noche Triste" in front of the Popotla's cypress. Photograph courtesy of the Proyecto Templo Mayor.

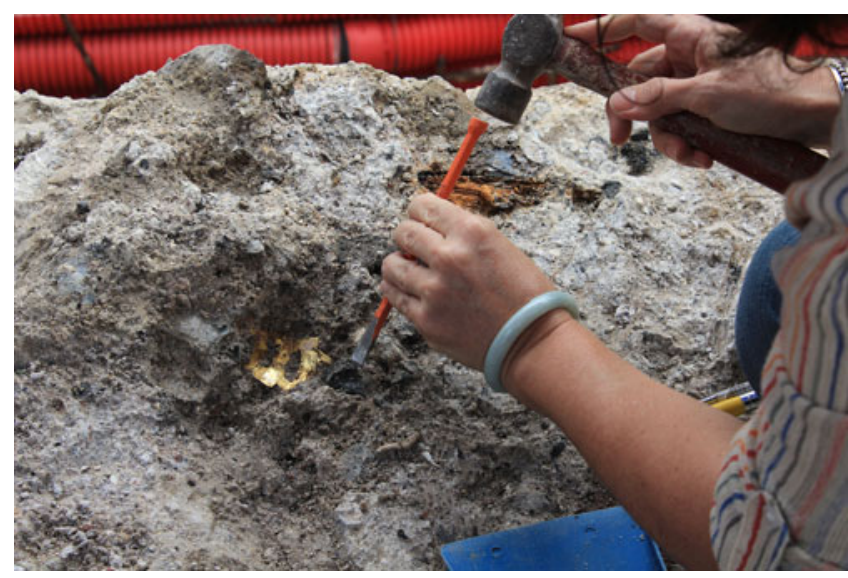

Figure 4. Excavation of Templo Mayor's offering 167 in 2016. Photograph courtesy of the Proyecto Templo Mayor.

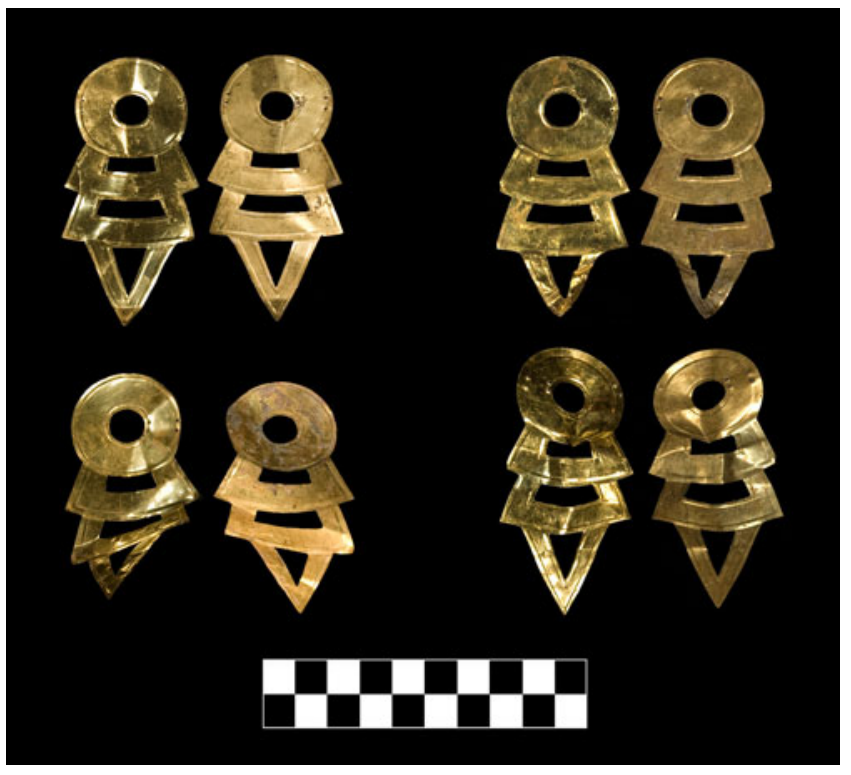

Figure 5. Offering 167: golden earpieces of the Moon Goddess, Coyolxauhqui. Photograph courtesy of the Proyecto Templo Mayor. 


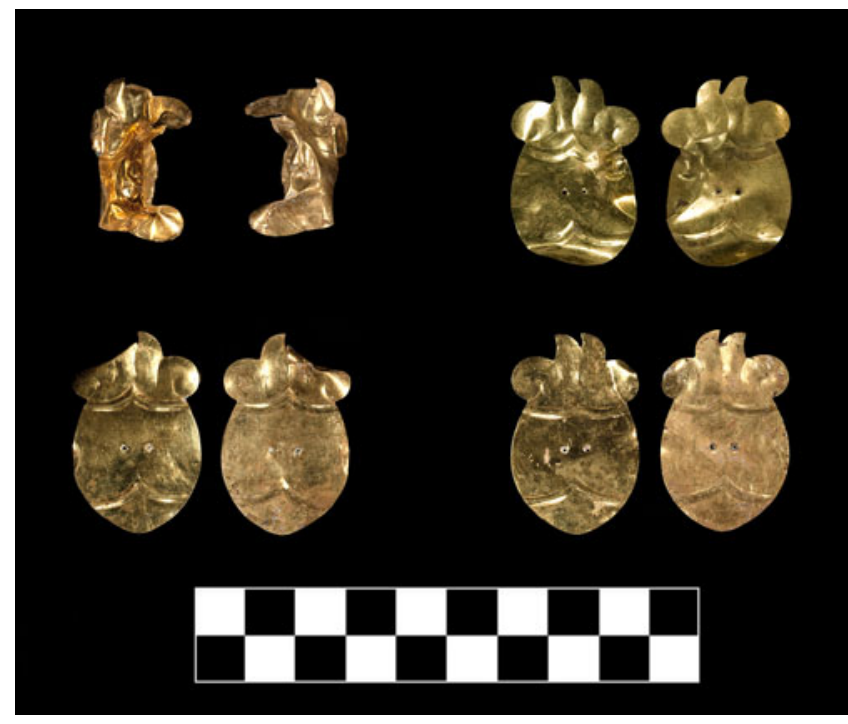

Figure 6. Offering 167: golden pieces representing human hearts. Photograph courtesy of the Proyecto Templo Mayor.

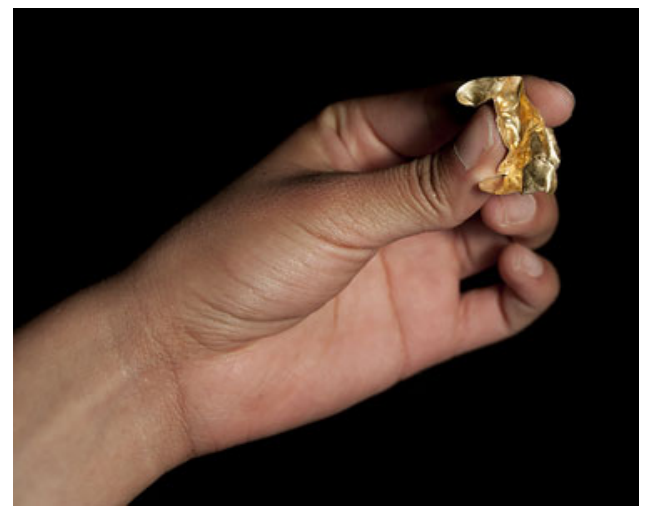

Figure 7. Offering 167: a human heart made of gold plate that was intentionally deformed. Photograph courtesy of the Proyecto Templo Mayor.

doubt that these pieces allude to the hearts of the goddess and her stellar siblings which, according to the version of the myth in the Crónica Mexicayotl (Alvarado Tezozómoc 1975:33-34), were devoured by Huitzilopochtli, an act interpreted by León-Portilla (1978a:22-23) as an appropriation of the vital energy of adversaries. One of the gold hearts that we found had clearly been deformed by the priest's hands (Figure 7). I wonder if this was intended to signify that Coyolxauhqui was "perverse," as inferred by the words yollochico and yollonecuil, literally translated as "crooked heart" and "bent heart" (Burkhardt 1989:177; León-Portilla 2004c; Molina 1944). Or maybe he wanted to "offend" the goddess magically or to "damage someone's heart," the literal sense of the verb teyolitlacoa (Burkhardt 1989:28-29; León-Portilla 2004c; Molina 1944). Although I still do not know the answer, I am confident that at the end of the day we will come to understand this priest's ritual gesture, for Miguel is always with us, the one who is the master of a wise face and a resistant heart like the trunk of a tree.

\section{Happy Birthday!}

... And may he now rest in peace.

\section{ACKNOWLEDGMENTS}

I am grateful to Eduardo Matos Moctezuma, Ana Carolina Ibarra, William R. Fowler, and Scott Sessions.

\section{REFERENCES}

Alcina Franch, José, Miguel León-Portilla, and Eduardo Matos Moctezuma 1992 Azteca-Mexica. Las culturas del México Antiguo. Sociedad Estatal Quinto Centenario, Lunwerg Editores, Madrid.

Alvarado Tezozómoc, Hernando

1975 Crónica Mexicáyotl. Universidad Nacional Autónoma de México, Mexico City.

Burkhardt, Louise

1989 The Slippery Earth: Nahua-Christian Moral Dialogue in Sixteenth-Century Mexico. University of Arizona Press, Tucson.

Garibay K., Ángel María

1959 Proemio a la serie Estudios de Cultura Náhuatl. Estudios de Cultura Náhuatl 1:5-8.

León-Portilla, Miguel

1956 La filosofía náhuatl, estudiada en sus fuentes. Ediciones Especiales del Instituto Indigenista Interamericano, Mexico City. [English edition: Aztec Thought and Culture: A Study of the Ancient Nahuatl Mind. University of Oklahoma Press, Norman, 1963.]

1959 Visión de los vencidos, relaciones indígenas de la conquista. Universidad Nacional Autónoma de México, Mexico City. [English edition: The Broken Spears: The Aztec Account of the Conquest of Mexico. Beacon Press, Boston, 1962.]

1960 Jornadas de Homenaje, Saturnino Herrán. América Indígena 20: 295-303.

1961 Los antiguos mexicanos a través de sus crónicas y cantares. Fondo de Cultura Económica, Mexico City. [English edition: The Aztec Image of Self and Society: An Introduction to Nahua Culture. University of Utah Press, Salt Lake City, 1992.]

1964 Las literaturas precolombinas de México. Editorial Pormaca, Mexico City. [English edition: Pre-Columbian Literatures of Mexico. University of Oklahoma Press, Norman, 1969.]

1967 Trece poetas del mundo azteca. Universidad Nacional Autónoma de México, Mexico City. [English edition: Fifteen Poets of the Aztec World. University of Oklahoma Press, Norman, 1992.]

1971 Guillermo Dupaix. Expediciones acerca de los antiguos monumentos de la Nueva España, 1805-1808. Anales de Antropología 8: 322-323.

1974a El teatro náhuatl. Universidad Nacional Autónoma de México, Mexico City.

1974b Historia de México, Vol. 3. Salvat Editores de México, Mexico City.

1974c Review of The Aztec Image in Western Thought by Benjamin Keen. Estudios de Cultura Náhuatl 11:378-382.

1974d Significación cultural del México prehispánico. In Trayectoria de la cultura en México, pp. 7-19. Fomento Cultural Banamex, Mexico City.

1978a México-Tenochtitlan: Su espacio y tiempo sagrados. Instituto Nacional de Antropología e Historia, Mexico City.

1978b Minería y metalurgia en el México antiguo. In La minería en México, pp. 5-36. Universidad Nacional Autónoma de México, Mexico City.

1978c Prefacio. In Guillermo Dupaix. Atlas de las antigüedades mexicanas halladas en el curso de los tres viajes de la Real Expedición de Antigüedades de la Nueva España, emprendidos en 1805, 1806 y 1807, pp. 9-11. San Ángel Ediciones, Mexico City.

1979. Tercer grado, ciencias sociales. México: Su evolución cultural. 3rd ed. Editorial Porrúa, Mexico City.

1980 Juan Comas Camps (1900-1979). Estudios de Cultura Náhuatl 14:433-434

1982 El Templo Mayor en la historia sagrada de los mexicas. Revista de la Universidad de México 38:20-24.

1983 Los primeros californios: Prehistoria y etnohistoria. In Panorama histórico de Baja California, edited by David Piñera Ramírez, pp. 15-45. Universidad Nacional Autónoma de México, Mexico City, and Universidad Autónoma de Baja California, Tijuana.

1984 La minería y la metalurgia en el México antiguo. In Minería Mexicana, pp. 3-30. Comisión de Fomento Minero, Mexico City. 
1987 The Ethnohistorical Record for the Huey Teocalli of Tenochtitlan. In The Aztec Templo Mayor, edited by Elizabeth Hill Boone, pp. 71-95. Dumbarton Oaks Research Library and Collection, Washington, DC.

1989 Review of Crónica en barro y piedra. Arte prehispánico en la Colección Sáenz by Jacqueline Larralde de Sáenz. Estudios de Cultura Náhuatl 19:488-493.

1992a El agua: Universo de significaciones y realidades en Mesoamérica. Revista Ciencias 28:7-14.

1992b Literaturas indígenas de México. Fondo de Cultura Económica MAPFRE, Mexico City.

1993 Mi egohistoria. In Egohistorias, edited by Jean Meyer, pp

85-102. Centre d'Études Mexicaines et Centraméricaines, Mexico City.

1995a La California mexicana: Ensayos acerca de su historia. Instituto de Investigaciones Históricas, Universidad Nacional Autónoma de México, Mexico City.

1995b Xochicalco en la historia. In La acrópolis de Xochicalco, pp. 35-86. Instituto de Cultura de Morelos, Mexico City.

1996 El destino de la palabra: De la oralidad y los códices mesoamericanos a la escritura alfabética. Fondo de Cultura Económica, Mexico City.

1997 Prólogo. In Viaje pintoresco y arqueológico a la provincia de Yucatán, pp. 11-31. Grupo Condumex, Mexico City.

2002 José Alcina Franch. Estudios de Cultura Náhuatl 33:351-352.

2004a La educación entre los mexicas. In Obras de Miguel LeónPortilla. Tomo ii. En torno a la historia de Mesoamérica, pp. 358-374. Universidad Nacional Autónoma de México, El Colegio Nacional, Mexico City.

2004b Significación cultural de Mesoamérica. In Obras de Miguel León-Portilla. Tomo II. En torno a la historia de Mesoamérica, pp. 385-400. Universidad Nacional Autónoma de México, El Colegio Nacional, Mexico City.

2004c Significados del corazón en el México prehispánico. Archivos de Cardiología de México 74:93-103.
2007 Quetzalcóatl: Dios y hombre omnipresente en Mesoamérica In Isis y la serpiente emplumada: Egipto faraónico/México prehispánico, pp. 138-151. Fundación Monterrey, Monterrey.

2008 Tula Xicocotitlan: Historia y arqueología. Estudios de Cultura Náhuatl 39:65-86.

2009 Manuel Gamio y el indigenismo. In Obras de Miguel LeónPortilla. Tomo IV. Biografías, pp. 539-558. Universidad Nacional Autónoma de México, El Colegio Nacional, Mexico City.

2011 Del tiempo: Vivencia e inferencia. In Obras de Miguel LeónPortilla. Tomo IX. De filosofía e historia, pp. 45-88. Universidad Nacional Autónoma de México, El Colegio Nacional, Mexico City.

León-Portilla, Miguel, and David Piñera Ramírez

2011 Baja California, historia breve. Fondo de Cultura Económica, Mexico City.

León-Portilla, Miguel, Eduardo Matos Moctezuma, and Dominique Verut 1981 El Templo Mayor. Bancomer, Mexico City.

López Luján, Leonardo

2015a Cincuenta y seis años de arqueología en Estudios de Cultura Náhuatl. Estudios de Cultura Náhuatl 50:31-51.

2015b Proyecto Templo Mayor: Informe de la octava temporada (fase 2014-2015). Report for the Consejo de Arqueología, Instituto Nacional de Antropología e Historia, Mexico City.

Molina, Fray Alonso de

1944 Vocabulario en lengua castellana y mexicana. Cultura Hispánica, Madrid.

Pedraza Rubio, Gerardo, Leonardo López Luján, and Nicolás Fuentes Hoyos 2017 Huesos cruzados y corazones torcidos: Una ofrenda con insignias de oro al pie del Templo Mayor de Tenochtitlan. Arqueología Mexicana 144:44-50.

Sahagún, Bernardino

1961 Florentine Codex: General History of the Things of New Spain. Book 10: The People. Edited and translated by Arthur J.O. Anderson and Charles E. Dibble. School of American Research, Santa Fe, and University of Utah, Salt Lake City. 